\title{
ゴム製器具からのジメチルアミンの溶出について*1
}

(昭和 54 年 7 月 11 日受理)

$\begin{array}{ll}\text { 馬場二夫*2 } & \text { 斉藤 } \\ \text { 谷口穣*2 } & \text { 福*2 井弥生*2 } \\ \text { 水谷泰久 } & \end{array}$

\section{Dimethylamine in the Extracts of Rubber Articles Used in Contact with Foods}

(Hygienic Chemistry of Rubber Articles Used in Contact with Foods. V)

Tsugio BABA*2, Minoru SAITo*2, Yayoi FUKUI*2,
Sigeru TANIGUCHI*2 and Yasuhisa MizUnOYA*3

(*2Osaka City Institute of Public Health and Environmental Sciences: 21, Tojo-cho, Tennoji-ku, Osaka; ${ }^{* 3}$ Osaka College of Pharmacy: 10-65, Kawai 2-chome, Matsubara, Osaka)

Dimethylamine (DMA) levels in the extracts of 25 rubber articles were studied by gas chromatography. DMA was detected in $\mathrm{H}_{2} \mathrm{O}$ or $1 \mathrm{~N} \mathrm{HCl}$ extracts of 15 samples obtained under reflux for 1 hour, in amounts of $3 \sim 1280$ and $17 \sim 2830 \mathrm{mg} / \mathrm{kg}$, respectively.

Vulcanizing accelerators containing dimethylamino groups in their structures were detected in benzene extracts of these rubber articles by thin layer chromatography.

Thiuram-type vulcanizing accelerators were almost completely decomposed to DMA on reflux with $\mathrm{H}_{2} \mathrm{O}$ or $1 \mathrm{~N} \mathrm{HCl}$ for 1 hour, but dithiocarbamate degradation varied very greatly depending on the kind of solvent and the salts present.

It can be concluded that DMA in rubber extracts is the decomposition product of vulcanizing accelerators containing dimethylamino group in their structures, and that DMA can be extracted fairly effectively from unaltered vulcanizing accelerators in rubber articles using $\mathrm{H}_{2} \mathrm{O}$ or $1 \mathrm{~N} \mathrm{HCl}$.

(Received July 11, 1979)

\section{はじめに}

第 2 級アミンはガン原性物質であるニトロソアミンの 前駆物質として注目され，すでにかなりの食品について その分布および含有量が調査されている1) 4) が，飲食物 用器具などについて調査した報告はみられない. 著者ら はこれまでゴム製品からの溶出物について種々検討を加 えてきたが，食品関係に使用されているこれらのものの 中にもジメチルアミン (DMA) を溶出するものがあるこ とを認めだ)。そこで，その実態をは握するため，先に

*1 飲食物用器具などに使用するゴム製品の衛生化学的 研究 (第 5 報)

*2 大阪市立環境科学研究所: 大阪市天王寺区東上町 21

*3 大阪薬科大学: 大阪府松原市河合 2-10-65
報告したガスクロマトグラフィー (GC) による直接定量 法"5を用い，これらゴム製品から溶出する DMA の定量 を行った。また検出された DMAの由来についても検討 した.

\section{実験方法}

1. 試料

1)ゴム製品

びん詰・弁当の菜入れ用パッキング, ゴムヘラ, 密封 栓, 乳首など家庭用のもののほか, 食品工㘹に拈いて使 用されているパイプジョイント用パッキング，ゴムホー ス，なな板および水道器具のパッキングなど25試料を対 象とした。 


\section{2) 加硫促進剤}

化学構造式の中にジメチルアミノ基を有するもの 6 種 類を用いた (Table 1).

\section{2. 試薬および装置}

$1 N$ 塩酸， 4 \%酢酸はいずれ子特級品を用いて調製し た、イソプロパノール (IPA) をはじめ試薬はすべて特 級品をそのまま使用した。

ガスクロマトグラフおよび遠心式粉砕機は先の 報告) と同じものを使用した。

\section{3. 試 験操作}

DMA の定量は先に報告した GC 法淿により行った。 すなわち試料がゴムの場合は液体窒素で冷却硬化した 後, 遠心式粉砕機を用いて粉砕し，その $10 \sim 20 \mathrm{~g}$ を, また加硫促進剂の場合は 10 50 mg をそれぞれ科取し， 水または $1 N$ 塩酸 $100 \mathrm{ml}$ を加えて 1 時間加熱還流し 前報5) と同様に 操作し 試験溶液を 調製した。ただし， IPA 浸出の試験溶液は試料に IPA $100 \mathrm{ml}$ を加え室温 で24時間漫漬し，そのろ液を用いた。

ゴム製品に含まれる加硫促進剤の確認は粉砕した試料 $2 \mathrm{~g}$ にベンゼン $20 \mathrm{ml}$ を加方室温で 24 時間浸漬した後ろ 過し，このろ液を試験溶液として薄層クロマトグラフィ

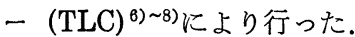

ゴム製品の材質は第 1 報河に記載した熱分解ガスクロ マトグラフィーにより判定した.

\section{実験結果および考察}

\section{1. ゴム製品から溶出する DMA}

食品関係に使用されている25種のゴム製品について，
水および $1 N$ 塩酸を溶媒として浸出し，溶出する DMA 量を測定した結果を Table 2 に示した。

試験したゴム製品25試料のうち15試料から DMA の溶 出が認められた。これを用途別にみると乳首以外のパッ キング，ホース，へラ，まな板などほとんどのゴム製品 にDMA の溶出が認められ，また材質別にみても天然ゴ ム，スチレンブタジェンゴム，クロロプレンゴムなどそ の種類に関係のないことがわかった.

DMA の溶出量は製品当たり水浸出では $3 \sim 1280 \mathrm{mg} /$ $\mathrm{kg}, 1 N$ 塩酸浸出では $17 \sim 2830 \mathrm{mg} / \mathrm{kg}$ で，いずれの 試料に括いても水浸出より $1 N$ 塩酸浸出の方が大きい值 を示した。

このようにゴム製品にも DMA を溶出するもののあ ることが確認され，食品関係に使用するゴム製品から DMA が食品へ移行する可能性のあることが同えた。

なお，各試料について IPA 浸出を行い，材質中の DMA を測定したが，DMA の溶出が認められた試料に ついてはその材質中からも 2 492 $\mathrm{mg} / \mathrm{kg}$ の DMA が 検出された。

\section{2.ゴム材質中に残留する加硫促進剤の確認}

ゴムの製造にあたり DMA を直接添加することは考兄 られないので，ゴムの浸出液から検出された DMA の由 来は化学構造式の中にジメチルアミノ基を有する加硫促 進剤によるものと推定される。

そこで，このことを確認するため Table 2 の試料の なかから No. 2，4，6，10，11怙よび16の 6 試料を選び， Table 1 に示した 6 種類の加硫促進剤を対照として材

Table 1. Vulcanizing Accelerator Containing Dimethylamino Group

Vulcanizing accelerator

Tetramethylthiuram monosulfide

Tetramethylthiuram disulfide

Sodium dimethyldithiocarbamate

Zine dimethyldithiocarbamate

Copper dimethyldithiocarbamate

Lead dimethyldithiocarbamate
Abbreviation Structure

TM S

T D S

Na-DMTC<smiles>CN(C)C(=S)SC(=S)N(C)C</smiles><smiles>CN(C)C(=S)SSC(=S)N(C)C</smiles><smiles>CN(C)C(=S)S[Na]</smiles>

Zn-DMTC

$\mathrm{Cu}-\mathrm{DMTC}$

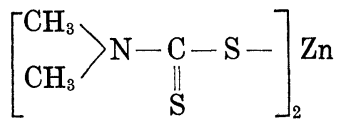<smiles>CCSC(=S)N(C)C</smiles>

Pb-DMTC 
Table 2. DMA Extracted from Rubbers with Various Solvents

\begin{tabular}{|c|c|c|c|c|c|c|}
\hline \multirow{2}{*}{ No. } & \multirow{2}{*}{\multicolumn{2}{|c|}{ Sample }} & \multirow{2}{*}{$\begin{array}{c}\text { Materials of } \\
\text { rubbers }\end{array}$} & \multicolumn{3}{|c|}{ DMA detected $(\mathrm{mg} / \mathrm{kg})$} \\
\hline & & & & Water $^{a)}$ & $1 N \mathrm{HCl}^{\mathrm{a})}$ & Isopropanol $^{\text {b) }}$ \\
\hline 1 & Packing for food industry & (A) & S B R & 330 & 448 & 78 \\
\hline 2 & $"$ & (B) & $"$ & 597 & 680 & 310 \\
\hline 3 & Packing for lunch-box & & $\mathrm{NR}+\mathrm{S} B \mathrm{R}$ & 67 & 124 & 10 \\
\hline 4 & Packing for bottle & (A) & NR & 180 & 246 & 135 \\
\hline 5 & $n$ & (B) & $\mathrm{NR}+\mathrm{S} B \mathrm{R}$ & 113 & 170 & 8 \\
\hline 6 & Packing for utensil & (A) & C R & $\mathrm{ND}$ & ND & $\mathrm{ND}$ \\
\hline 7 & " & (B) & $"$ & 153 & 167 & 5 \\
\hline 8 & $"$ & (C) & $\mathrm{NR}$ & 20 & 23 & 14 \\
\hline 9 & $"$ & (D) & N B R & 213 & 237 & 22 \\
\hline 10 & $n$ & $(\mathrm{E})$ & $n$ & 1,280 & 2,830 & 492 \\
\hline 11 & $"$ & $(\mathrm{~F})$ & $\mathrm{CR}$ & ND & ND & ND \\
\hline 12 & $"$ & $(G)$ & $"$ & ND & ND & $\mathrm{ND}$ \\
\hline 13 & $n$ & $(\mathrm{H})$ & $"$ & $\mathrm{ND}$ & $\mathrm{ND}$ & ND \\
\hline 14 & Stopper for bottle & & $\mathrm{NR}+\mathrm{S} \mathrm{BR}$ & 17 & 23 & 7 \\
\hline 15 & Hose for food industry & & N B R & 3 & 25 & 2 \\
\hline 16 & Chopping board & (A) & " & 27 & 60 & 20 \\
\hline 17 & $n$ & (B) & $"$ & 17 & 17 & 11 \\
\hline 18 & Spatula & (A) & $\mathrm{NR}+\mathrm{EPR}$ & 34 & 150 & 8 \\
\hline 19 & " & (B) & $\mathrm{NR}+\mathrm{SBR}$ & 71 & 222 & 5 \\
\hline 20 & Nipple & (A) & I R & ND & ND & ND \\
\hline 21 & $n$ & (B) & $"$ & $\mathrm{ND}$ & ND & ND \\
\hline 22 & $"$ & (C) & $" \prime$ & ND & ND & $\mathrm{ND}$ \\
\hline 23 & $"$ & (D) & $"$ & ND & ND & ND \\
\hline 24 & $"$ & (E) & NR & ND & $\mathrm{ND}$ & ND \\
\hline 25 & $"$ & $(F)$ & $n$ & ND & $\mathrm{ND}$ & ND \\
\hline
\end{tabular}

a) Extracted under refluxing for one hour

b) Extracted for 24 hours at room temperature

SBR, Stylene Butadiene Rubber NR, Natural Rubber

NBR, Nitrile Butadiene Rubber IR, Isoplene Rubber

CR, Chloroplene Rubber

EPR, Ethylene Propylene Rubber

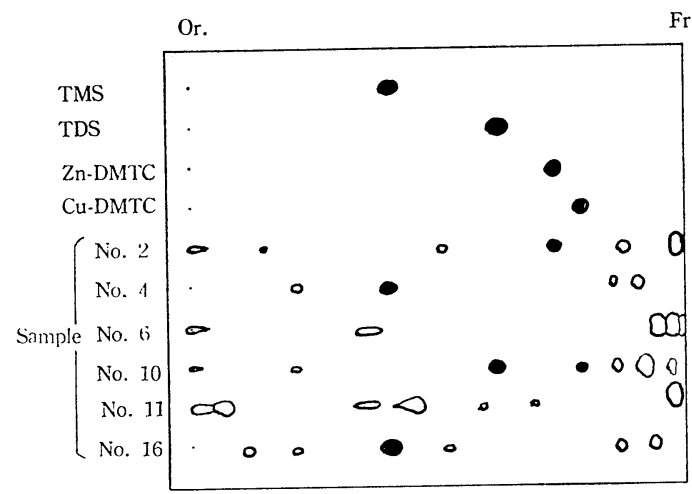

Fig. 1. Thin-layer chromatogram of vulcanizing accelerators and rubber extracts Solvent: benzene-ethyl acetate-acetone $(100-5-1)$
質中に残留しているこれら化合物の検索を行った。 その 結果, Fig. 1 に示したように No. 2 の試料から ZnDMTC, No. 4 および No. 16 の試料から TMS, No. 10 の試料から TDS および Cu-DMTC をそれぞれ検出 した。これらはいずれもさきの溶出試験で DMA の溶出 が磪認された試料である。また，DMA の溶出が認めら れなかった No. 6 および No. 11 の試料からは Table 1 の加硫促進凧は検出されなかった。 すなわち, 化学構 造式中にジメチルアミノ基を有する加硫促進剂が確認さ れたゴム製品からのみ DMA の溶出がみられることがわ かった。

\section{3. 加硫促進剤の分解による DMA の生成}

Table 2 に示したよらにゴム製品からの DMA の溶 出量は，使用した浸出溶媒によって異なり，いずれの試 料についても水より $1 N$ 塩酸の方が大きい値が得られ 
Table 3. Effect of Solvents for Decomposition of Vulcanizing Accelerators

\begin{tabular}{|c|c|c|c|c|}
\hline \multirow{2}{*}{$\begin{array}{l}\text { Vulcanizing } \\
\text { accelerator }\end{array}$} & \multirow{2}{*}{$\begin{array}{c}\text { Theoretical DMA } \\
(\mathrm{mg} / 100 \mathrm{mg})\end{array}$} & \multicolumn{3}{|c|}{ DMA found $(\mathrm{mg} / 100 \mathrm{mg})$} \\
\hline & & Water $\left.^{a}\right)$ & $1 N \mathrm{HCl}^{\mathrm{a})}$ & Isopropanol $^{\mathrm{b})}$ \\
\hline $\mathrm{TMS}$ & 43.3 & $41.8(96.6)$ & $43.9(101.3)$ & 0.04 \\
\hline T D S & 37.5 & $35.9(95.7)$ & $36.7(97.9)$ & 0.04 \\
\hline $\mathrm{Na-DMTC}$ & 31.5 & $12.0(38.1)$ & $14.3(45.4)$ & 0.09 \\
\hline $\mathrm{Zn-DMTC}$ & 29.4 & $7.9(26.9)$ & $26.8(91.2)$ & 0.02 \\
\hline $\mathrm{Cu}$-DMTC & 29.6 & $0.4(1.4)$ & $23.4(79.1)$ & 0.01 \\
\hline $\mathrm{Pb}-\mathrm{DMTC}$ & 20.1 & $0.1(0.5)$ & $17.9(89.1)$ & 0.02 \\
\hline
\end{tabular}

( ): Decomposition percent (\%)

a) Reflux with each solvent for one hour

b) Immersed the sample in IPA for 24 hours at room temperature

た。これは材質中に残留するジメチルアミノ基を有する 加硫促進剤が浸出時に分解して DMA を生成することを 示唆している. そこで Table 1 に示した 6 種類の加硫 促進剤について，水および $1 N$ 塩酸を用いてゴム製品 の場合と同様の処理を行い，DMA の生成状況を検討し た。そこの結果, Table 3 に示したように TMS, TDS は 水, $1 N$ 塩酸いずれの溶媒で煮沸してもほぼ理論値の DMA を生成し $100 \%$ 近い分解率を示した。これに対し $\mathrm{Cu}$-DMTC, Pb-DMTC は水で煮沸しても分解しないが， $1 N$ 塩酸で煮沸すると，そのほとんどが分解して理論值 の80 90\%の DMA を生成した。 また同じジチオカルバ ミン酸塩でも Na-DMTC，Zn-DMTC は水で劣沸する とその $1 / 3$ 程度が分解して理論值の $25 \sim 40 \% の \mathrm{DMA} を$ 生成し, $1 N$ 塩酸で煮沸すると Na-DMTC は水での煮 沸とそれほど変らないが，Zn-DMTCはそのほとんどが 分解して理論值の約 $90 \%$ の DMA を生成した。ちなみ に，これら加硫促進剤を IPA で浸出し夾雑する DMA を测定したが，各試料ともとの值は $0.1 \%$ 以下であった。

以上の実駼結果から，ゴムの材質中にこれらの加硫促 進剂が残留している場合，浸出時にとれが分解されて DMA を生成することがわかった，しかしながら， Table 2 において DMA の溶出が認められた試料について は，いずれもその材質中に DMA の存在が認められてい る.これはゴムの加工に際して使用した加硫促進剤が， その加硫工程で分解生成した DMA の一部残留したもの と考えられるが，ゴム製品からの DMA の溶出量にはこ れらの DMA も加わっているものと解される.

\section{まとめ}

食品関係に使用されているゴム製品から溶出する DMA の実態を調べた。各種ゴム製品25試料のうち乳首 などを除く15試料から DMA が検出され，製品当たり水 浸出で $3 \sim 1280 \mathrm{mg} / \mathrm{kg}, 1 N$ 塩酸浸出で $17 \sim 2830 \mathrm{mg} /$ $\mathrm{kg}$ の溶出が認められた。 そして DMA が検出された試 料から，化学满造式の中にジメチルアミノ基をもつチウ
ラム系あるいはジチオカルバメート系の加硫促進剤が検 出されたことと, それら加硫促進剂を水または $1 N$ 塩酸 で煮沸すると DMA を生成することが確認されたことか ら, ゴムから検出された DMA の由来は加硫促進剂によ るものと推察された。

今回の調查結果から，ゴム製品から DMA が食品へ移 行する可能性のあることが明らかとなったが，それらの 製品から移行すると考えられる DMA 量は魚肉などに含 有されている DMA 量1) 亿) に比べてはるかに微量で，今 ただちにこれを危険視する必要はないと考える。しか し，たとえ微量であっても食品污染は好ましいことでは ないので，食品関係に使用するゴム製品については，今 後加硫工程等を再検討して DMA を溶出しない製品が提 供されるよう望まれる。

\section{謝辞}

終りに臨み，本研究に御指導御䇝墶をいただいた大阪 市立大学医学部大和田国夫教授に深く感謝します。また 本研究に当たり多大な御協力を賜わった大阪市環境保健 局食品衛生課の各位に深謝します。

なお本研究の要旨は日本薬学会第98年会 (1978年, 岡 山）において講演発表した。

\section{文献}

1）伊藤誉志男, 作田広子, 横田重俊, 鮎川郁子, 谷 村顕雄：食衛誌. 12, 185 191 (1971).

2) 河村太郎, 堺 敬一, 宮沢文雄, 和田 裕, 伊藤 誉志男, 谷村顕雄: 同上, 12, 192 197 (1971).

3) 河村太郎, 堺 敬一, 宮沢文雄, 和田 裕, 伊藤 誉志男, 谷村顕雄: 同上, 12, 394 398 (1971).

4) 国崎直道, 松浦宏之, 松浦京子, 林 誠: 同上, 17, $410 \sim 412$ (1976).

5) 馬場二夫, 斉藤 銥, 福井弥生, 谷口 繁, 大和 田国夫，水谷泰久：同上, 19, $530 \sim 535$ (1978).

6) 湯浅 輝, 神谷和子：分析化学, 13, $966 \sim 970$ (1964). 
7）長沢一彦, 太田一男：同上, 16, 1285 1290 (1967).

8) Kreiner, J.G., Warner, W.C.: J. Chromatog., 44, 315 330 (1969).
9）馬場二夫，楠本一枝，水谷泰久：彾衛誌。 20 , $396 \sim 401$ (1979). 